\title{
Revision Program of the Co- Operative Study of Secondary- School Standards
}

\section{GEORGE E. CARROTHERS}

$\mathbf{T}$ HE General Committee on the Co-operative Study of Secondary-School Standards held a meeting in February, 1948, in connection with the mid-winter educational meetings in Atlantic City. The purpose of the meeting was to consider accomplishments to date in the revision program of the Study and to outline plans for the next eighteen months of work. Sixteen members or their representatives and Dr. George F. Zook of the American Council on Education were present. Mr. A. J. Cloud came all the way from California, Dr. Franzén sent his proxy from Germany where he is Educational Adviser for the Secondary Schools of Bremen, and Professor Joseph Roemer came from Florida where he is attempting to get a few days of vacation between semesters. The Committee considered and adopted plans for the rest of the revision program. It then authorized the Administrative Committee to continue carrying the supervision of the work until it is completed.

The Administrative Committee, consisting of Professors E. D. Grizzell and Joseph Roemer, Mr. Carl A. Jessen of the U. S. Office of Education, and the writer, had already been able to obtain Dr. Roy O. Billett of Boston University as the Director of the Revision Study for the calendar year 1948 and 1949 on the half-time basis. Rooms have been rented at 131 Clarendon Street, Boston, Massachusetts, and the revision office opened January 1, 1948. A research assistant, James F. Baker, and a secretary have been employed. The revision activities are already well underway as this is being written in March, 1948.

George E. Carrothers, Director of the Bureau of Co-operation with Educational Institutions of the University of Michigan in Ann Arbor, Michigan, is Chairman of the General Committee on the Co-operative Study of Secondary-School Standards. 


\section{FINANCING THE PROGRAM}

The Committee has made every effort to conserve and invest funds during the intervening years since the publication of the Study in 1940 in order to have at least a small reserve for use in starting the revision. We came through with approximately ten thousand dollars on hand. The regional associations were again asked to contribute to the fund, and each responded promptly with support. Four of the associations have made appropriations of about fifty cents per school for the first year of the revision period, and two-the New England Association and the Western Association-have each sent a lump sum. Some of the associations have agreed to make similar appropriations for the second year of the revision study; probably all will do the same.

At first it appeared that about $\$ 60,000$ would be necessary for the two and one-half years of work, $\$ 47,000$ of which it was hoped to obtain from the General Education Board or some other foundation. At the meeting of the General Committee on March 2, 1947, in Atlantic City and at later conferences, we learned that it would not be possible to secure an amount that large from that Foundation. We started then to rearrange the undertaking and adjust plans for the revision. It was decided that the time could be reduced from two and one-half down to two years, that we could place the headquarters office at the University where the Director would reside, that an able man could be obtained on the half-time basis, and that we could secure a number of graduate students to assist in the evaluation of the literature and the summarizing of reports under the direction of professors of secondary education, just as we did in the original study. The principal financial economy, however, was'effected by a plan to secure a great deal of donated time from organizations and individuals. These and other econcmies made it possible to arrange for a satisfactory revision for an outlay of about $\$ 40,000$ in actual cash, which the committee now has on hand or is confident of securing. The American Council on Education, Washington, D. C., is acting as the financial agent for the revision program.

REVISION PLANNED EARLY

Even from the beginning of the Study the Committee had in mind making a revision someday. Plans were laid in 1940 for collecting information, opinions, suggestions, and recommendations from persons who would be using the criteria in cvaluations, as well as from professors of secondary education who would use them in college courses. The Washington office, under the able secretaryship of Carl A. Jessen, annually sent requests 
for the names of all school men and women who assisted in evaluations of schools. To each of these a prepared form was sent asking for reactions and opinions. The forms and reports were sent to Secretary Jessen and retained in the Washington office. These responses and recommendations are from those school men who have participated in two or more scheduled evaluation programs. All of these men have had firsthand experience in the use of the criteria and other materials.

The General Committee decided on a second line of action to obiain intormation on the strengths and weaknesses of the criteria and procedures when placed in actual operation. A questionnaire was developed for use with administrators of all schools which had experienced evaluations. The abjective was similar to that of the opinionnaire study, only this time it was to discover the reactions of the evaluated schools rather than opinions of evaluators. The purpose was to have men whose schools had been evaluated give their reactions to the whole process and content of the evaluation as a basis for modifications and improvements to be incorporated in a future revision.

Both sets of questionnaires were sent out from the Washington office by Secretary Jessen during the past several years. All reports were collected and retained in the files for use at any time a revision program might be undertaken. The anticipation of a need for a revision someday and the definite early planning to securc intormation, opinions, and suggestions from the persons most closely associated with the use of the evaluative materials are now clearly shown to have been valuable procedures. If we had not secured and retained these frank statements from men in the field, it would be difficult for even the Committee members to realize how extensively "each evaluation created new enthusiasm, brought new ideas into all fields of the curriculum, school administration, improvement of the staff; etc."

\section{A STUDY OF OPINIONS MADE}

The numerous reports and opinions of members of evaluating committees were turned over for study to Dr. Carl G. F. Franzén, Professor of Education at Indiana University, who is chairman of the North Central Association Committee for Indiana and a member of the Co-operative Study Committee. Dr. Franzén devoted a great deal of time, attention, and effort to a careful analysis of these reports. He summarized the replies in an article which appears elswhere in this issue of The Bulletin of the National Association of Secondary-School Principals. Anyone interested in the opin-

Taken from one of the reports. 
ions of school men who have had experience in the use of the criteria and other materials in school evaluations will find Dr. Franzén's article well worth reading.

Replies received to the secund questionnaire came from those principals and other school administrators who were in charge of the school evaluated. The purpose of the "opinionnaire" was to obtain reactions of those who did the evaluating in schools which they had not previously known. The purpose of the second request, that of the questionnaire, was to obtain the reactions of those men whose schools had been evaluated. We wanted to learn what an administrator thought of the process after he had been through it. Again, Dr. Franzén did a careful, thoughtful job of analyzing the replies and reports. This article likewise appears elsewhere in this issue of THE Bulletin of the National Association of Secondary-School Principals. In the opinion of Dr. Franzén, the second is the more significant of the two. Both are well worth careful reading.

The Director of the revision program and his research assistant in the Boston office, with the help of several graduate students, are making a further study of these several hundred replies. Dr. Billett is finding, as Dr. Franzen found, that the suggestions, opinions, and recommendations sent in soon after the evaluations and while the experiences were fresh in their minds are of inestimable value at this time as we start on the new activities.

The revision program as now planned will be fundamental and creative and not merely an improvement on the materials and methods already available. Some of the changes will be far reaching. On the other hand, the Committee will not, except for demonstratedly good reasons, cast aside any of the materials already developed. The general organization and arrangement of the criteria in the revised edition will probably resemble quite closely the present published volume and separate pages. The manual, however, will doubtless have a greater number of changes and improvements made in it.

\section{CO-OPERATION GIVEN}

The widespread interest in the value and usefulness of the Co-operative Study materials is proving to be of genuine help at this time. A considerable number of educational organizations, institutions, and societies has volunteered to work with the Committee and the Director during the period of revision. Among these volunteers, the following might be mentioned. The School of Education of Boston University, at no expense to the Co-operative Study, has opened up a laboratory for work on "Improved Methods of 
Evaluating Secondary Education." In this laboratory, forty-three unusually capable teachers, principals, and specialists in one or another area of secondary education, some of whom are nationally known, are contributing time and thought to the study and improvement of published materials. Fifty students enrolled in the Graduate School of Boston University are also working in the laboratory for credit and are assisting in the study.

The Massachusetts Industrial Education Society has appointed a committee of three of their ablest members to assist during the period of the revision in the improvement of the criteria and procedures in the industrial arts area. Persons interested in, and members of, library associations, guidance groups, and others have definitely indicated their interest in the program and their willingness to be of assistance. Also, the Director is receiving in the Boston office gratifying indications of co-operation from state departments of education and other state organizations. Some of the educators and associations are sending in printed materials which they are using locally or are planning to use in evaluating school programs or in accrediting schools, with the suggestion that these be analyzed and compared with Co-operative Study materials. Helpful letters frequently accompany the printed materials suggesting improvements, and requesting Co-operative Study materials which they may examine. These volunteer services come from widespread areas. As many of the volunteers as possible are being used in the study of changes which ought to be made in the criteria and procedures.

One of the chief values of the Study, probably a unique value, is the provision that secondary-school teachers and administrators are to do the measuring or evaluating of the school. In the course of carrying on several hundred evaluations, literally thousands of teachers have expericnced personal growth in their understanding of what it takes to make an efficient inscitution in the area of secondary education. Many evaluators declare that participation in one of these planned school surveys has been of greater benefit to them than attending a surnmer session in a school of education.

We are pleased to report that the work of revision has started auspiciously. The Co-operative Study materials have had wide use, but there are indications that they can and will be reproduced in still better form and that they will be used even more extensively. It should be remembered, however, that the present materials are still being published, sold, and used in secondary schools. They can be purchased from the business office of the Study, The American Council on Education, 744 Jackson Place, Washington 6, D. C. The new materials will not be available until 1950 . 